\title{
OSHA looks at occupational regulations for recombinant DNA use
}

REFLECTING the increasingly rapid movement of recombinant DNA techniques from the research laboratory to the industrial production line, occupational health agencies in Washington are beginning to discuss how they should handle any health hazards that may be involved.

Dr Eula Bingham, Assistant Secretary of Labour and head of the Occupational Safety and Health Administration (OSHA), has suggested that an expert panel be set up to address the hazards of DNA use "particularly as they apply to potential occupational exposures".

In a letter to Dr Donald Fredrickson, Director of the National Institutes of Health, Dr Bingham says she supports the system of voluntary compliance by private industry with the NIH guidelines which, after a period of public comment, was implemented last week.

But she adds that the agency feels that "more formalised enforcement of procedures and rules within the regulated private sector is warranted" - a feeling shared with Senator Adlai Stevenson $\mathrm{Jr}$ who last week introduced a bill into the US Senate requiring mandatory registration of all appropriate experiments not currently covered by the guidelines.

Dr Bingham has suggested that the new panel should be established under the chairmanship of Dr David Rall, Director of the National Institute of Environmental Health Sciences - and that it should include not only members of the NIH's Recombinant DNA Advisory Committee, but also technical representatives from unions, management and public interest groups.

She also suggests that OSHA might review the NIH guidelines and publish them as interim guidelines for industry. "While these do not hold the force of regulations, they would indicate our support for control in this area and would also produce information to employees indicating what we feel are appropriate precautions and procedures of recombinant DNA use"'.

Dr Anthony Robbins, Director of the National Institute of Occupational Safety and Health (NIOSH) told Nature this week that he agreed with OSHA that the time was appropriate for detailed consideration of the implications of occupational exposures. Commenting on the fact that, in the past, OSHA has been reluctant to involve itself in the debate over the safety of occupational activities involving recom- binant DNA techniques, Dr Robbins said that previously the agency had hoped this would be done elsewhere. "Since no one else seems to be doing this, it seems to be the time to move", he said.

$\mathrm{NIOSH}$ is, in particular, suggesting that a registry be set up of all workers involved in such actitivies to enable the long term health effects to be adequately monitored.And as a precedent, he points to the recent decision by the Swedish government to set up a commission on the occupational hazards chaired by the head of the National Labour Protection Board.

No response to Dr Bingham's proposals has yet been formally received from $\mathrm{Dr}$ Fredrickson, who last week issued virtually unchanged revisions to the NIH guidelines which he had proposed last November and which significantly reduce containment requirements for a wide range of experiments.

In particular, Dr Frederickson has implemented his proposals that most experiments involving the bacterium Escherischia coli $\mathrm{K}-12$ be reduced to P1 plus EK1 containment levels, and that such experiments no longer need be registered with the NIH.

In announcing his decision, Dr Fredrickson said that he had received five letters of comment suggesting that the relaxation of the guideline was premature. However he had also received more than 170 letters giving general approval to the proposed changes, which he had decided to implement as originally suggested.

Dr Fredrickson's announcement, widely welcomed in the scientific community, coincided with the introduction of the bill tightening up the requirements for private industry introduced by Senator Stevenson, chairman of the Senate Subcommittee on Science and Space. Explaining the general purpose of his bill, Senator Stevenson said that in a time of general concern about the health of industrial innovation, the conditions surrounding recombinant DNA research seemed "unusually favourable" for the achievement of significant innovation - and that in the circumstances government regulations should not be undertaken lightly.

"However the modest registration requirement $I$ propose is justified as a minimal precaution against inadvertent harm to public health or the environment. Far from impeding the orderly progress of the research and its commercial exploitation, mandatory registration may actually facilitate it."

\section{Earth sciences and remote sensing agreements signed with China}

THE United States and the People's Republic of China last month signed two protocols for scientific and technological cooperation in earthquake studies and earth sciences, as well as a memorandum of understanding on the use of the Landsat earth resources monitoring satellite.

The signing of these accords came almost exactly a year after President Carter and Vice-Premier Deng Xiaoping signed a general agreement on scientific and technological cooperation between the two countries in Beijing (Peking).

The earthquake studies protocol includes cooperation in earthquake prediction, earthquake hazards evaluation and earthquake engineering, as well as other related basic and applied studies. Joint research in these areas is to begin immediately.

The other protocol covers research in areas such as marine resources, energy resources, marine geology and geotectonics. The two protocols cover various forms of cooperation between scientists in the two countries, including exchange visits, joint organisation of scientific conferences, symposia and lectures, and the exchange of specimens and standard samples.

Under a separate agreement with the National Aeronautics and Space Administration the People's Republic will purchase a ground station to receive, process, archive and disseminate earth resource data from the Landsat $\mathrm{D}$ satellite.

The station will be located near Beijing and the Chinese Academy of Sciences has agreed to help share in the cost of operating the satellite by paying an annual access fee of $\$ 200,000$, beginning six months after the station starts to receive data.

Other areas agreed by the Commission for possible future cooperation included aviation, statistics, nuclear energy (including nuclear physics and nuclear fusion), electronics and telecommunications. Administration officials in Washington last week rejected suggestions that moves to improve scientific and technological links with the People's Republic of China were directly related to the recent cooling of political and scientific relations with the Soviet Union.

Appearing before a Congressional committee hearing, Dr Frank Press, Director of the Office of Science and Technology Policy, said that scientific exchanges with China had been a positive element in the process of normalising USChina relations.

David Dickson 